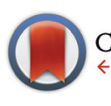

CrossMark \&lick for updates

Cite this: Dalton Trans., 2015, 44 3557

Received 6th August 2014,

Accepted 4th October 2014

DOI: $10.1039 / c 4 d t 02392 \mathrm{~g}$

www.rsc.org/dalton

\title{
Synthesis, cytotoxicity, DNA interaction and cell cycle studies of trans-diiodophosphine Pt(II) complexes $\uparrow$
}

\author{
Angeles Medrano, ${ }^{a}$ Stephen M. Dennis, ${ }^{b}$ Amparo Alvarez-Valdés, ${ }^{a} J^{\prime}$ osefina Perles, ${ }^{c}$ \\ Tracey McGregor Mason*b and Adoracion G. Quiroga*a
}

\begin{abstract}
Platinum complexes, bearing aliphatic amines and phosphine ligands in trans configuration with iodide as leaving groups, are synthesized and characterized. The crystal structure of trans- $\mathrm{Ptl}_{2}$ (isopropylamine)$\left(\mathrm{PPh}_{3}\right)$ is reported. The complex bearing isopropylamine is demonstrated to be the best candidate as its cytotoxic activity is comparable to or better than cisplatin. A remarkably higher interaction of the complexes with DNA is reported as compared to the parent chlorido series. Cell cycle studies of the complexes in six human cell lines are performed and also compared with the previous series.
\end{abstract}

\section{Introduction}

The discovery of new metallodrugs that can overcome the unwanted effects produced by cisplatin (currently the most efficient metallodrug in the clinic) has been extended in the past decades to new platinum analogues with a design that goes against the cis configuration requirement established by cisplatin. ${ }^{1}$ The activity of trans platinum complexes of the form trans- $\left[\mathrm{PtCl}_{2}(\mathrm{~L})\left(\mathrm{L}^{\prime}\right)\right]$ were reported in the early nineties, demonstrating that synthetic variations in the coordinating ligands may lead to new active species. ${ }^{2}$ Using aliphatic amines as spectator ligands, our research group was also able to demonstrate that active trans $\mathrm{Pt}$ (II) complexes were achievable. ${ }^{3}$ The combination of aliphatic amines in the trans geometry with other ligands has further proved that antitumor action is not only possible but also can be increased in some cases. ${ }^{4}$ In fact, phosphine ligands with hydrophobic character have been shown to increase cytotoxicity, possibly caused by the enhancement of cellular membrane transfer., ${ }^{5,6}$ The molecular mechanism of trans complexes bearing aliphatic amines starts with (as with most platinum complexes) the hydrolysis reaction. Mechanistic studies in aqueous solution also revealed the importance of the type of ligands bound to the platinum atom, ${ }^{7}$

\footnotetext{
${ }^{a}$ Department of Inorganic Chemistry, Universidad Autónoma de Madrid, C/Francisco Tomas y Valiente 7.M7, 28049 Madrid, Spain. E-mail: adoracion.gomez@uam.es; Fax: (+)34 914974850; Tel: (+)34 914974050

${ }^{b}$ Department of Chemistry, Stevenson University, 1525 Greenspring Valley $R d$,

Stevenson, MD 21153, USA.E-mail: tmason@stevenson.edu

${ }^{c}$ SIDI, Universidad Autónoma de Madrid, 28049 Madrid, Spain

$\dagger$ Electronic supplementary information (ESI) available: Crystallographic data and CIF, and diffraction data. CCDC 982662. For ESI and crystallographic data in CIF or other electronic format see DOI: $10.1039 / \mathrm{c} 4 \mathrm{dt} 02392 \mathrm{~g}$
}

but recent studies have demonstrated that using an iodide as leaving group, particularly in the cis geometry, ${ }^{8}$ may have an important role in the reactivity versus some biological targets.

The enhanced cytotoxicity achieved with trans complexes bearing phosphine ligands and aliphatic amines, along with our latest results using iodide as leaving groups, prompted us to synthesize and study the combination of these variations; the final compounds prepared are shown in Scheme 1.

The knowledge gained of tumor-associated cell cycle defects have provided excellent information for the design of anticancer compounds, ${ }^{9,10}$ but there are few studies of this type that can particularly help in the design of metallodrugs.

It is known that normal cells treated with cisplatin produce cell cycle arrest at the G2 phase of the cell cycle, which coincides with the induction of Nucleotide Excision Repair, the main pathway through which DNA-Pt lesions are removed. ${ }^{11,12}$ It has also been reported that interstrand adducts induced by some trans platinum compounds might provide G1 and S-phase arrest, allowing only low levels of progression towards G2/M phase. DNA damage would then shunt the cell toward apoptosis and cell death from G2/M. ${ }^{13,14}$

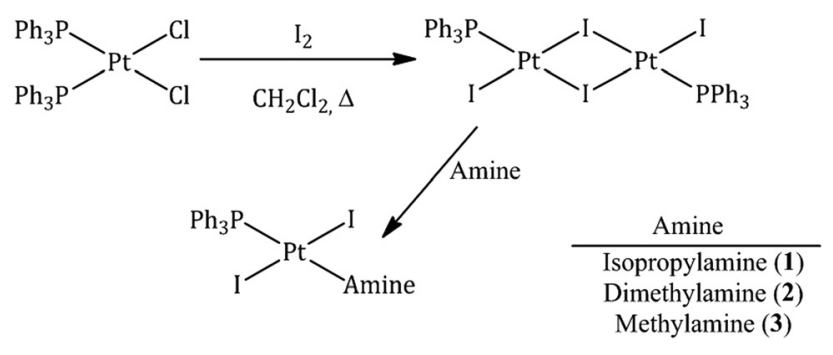

Scheme 1 General route of synthesis use to prepare the complexes. 
However, our data have indicated that some trans complexes can induce a higher accumulation of cells into $\mathrm{S}$ phase which does not translate into differential cytotoxic effects, ${ }^{5}$ providing evidence that further exploration is needed to determine if a possible differential mechanism of action indeed exists.

With these novel complexes, we are interested to know if the trans platinum complexes of Scheme 1 illicit the same cell cycle arrest pattern as the previously reported complexes and to compare these results in terms of the cytotoxicity data previously reported..$^{5,13,15}$

\section{Results and discussion}

\section{Chemistry}

The synthesis of these three novel complexes was achieved in a two-step procedure. First, the reaction of $\mathrm{I}_{2}$ with cis$\left[\mathrm{PtCl}_{2}\left(\mathrm{PPh}_{3}\right)_{2}\right]$ afforded the dinuclear complex trans- $\left[\mathrm{Pt}_{2} \mathrm{I}_{2}-\right.$ $\left.(\mu-\mathrm{I})_{2}\left(\mathrm{PPh}_{3}\right)_{2}\right]$ in a good yield. Longer reaction times did not aid in the formation of the dinuclear complex; on the contrary, the isomerisation of the dinuclear complex takes place, and a mixture of cis and trans platinum dinuclear complex was detected (at -3853.5 and -4775.3 in the ${ }^{195} \mathrm{Pt}$ NMR spectra). This mixture can be used as the intermediate compound as well in the synthesis of the final trans complexes.

Using cis- $\left[\mathrm{PtI}_{2}\left(\mathrm{PPh}_{3}\right)_{2}\right]$ as starting material allowed an earlier detection of the dinuclear complex, but it never resulted in a major species; as the reaction proceeded it produced a complicated mixture of polynuclear complexes in which the desired dinuclear complex was not visible after $24 \mathrm{~h}$ (monitoring the reaction by ${ }^{31} \mathrm{P} \mathrm{NMR}$ ). The second step is the cleavage of the dinuclear complex by the direct reaction of isopropylamine to produce complex $\mathbf{1}$, or by the slow addition of an equivalent amount of $\mathrm{NaOH}$ to an aqueous solution of the hydrochloric salt to produce complexes 2 and 3.

The characterization of these complexes, including the intermediate complexes, ${ }^{16,17}$ was carried out by the techniques of IR and ${ }^{195} \mathrm{Pt},{ }^{31} \mathrm{P},{ }^{1} \mathrm{H}$ and ${ }^{13} \mathrm{C}$ NMR. All of the microanalytical data was consistent with the empirical formulas, and the values of the coupling constant and chemical shifts of the ${ }^{31} \mathrm{P}$ and ${ }^{195} \mathrm{Pt}$ NMR were in accordance to similar compounds reported in the literature. .,18,19 $^{5}$

\section{Crystal structure of complex 1}

The structure of complex 1 was determined by single crystal X-ray diffraction. The molecular species trans- $\mathrm{PtI}_{2}(\mathrm{ipa})\left(\mathrm{PPh}_{3}\right)$ displays a Pt atom located in a distorted square planar environment. The metal center is coordinated to one phosphorus, one nitrogen and two iodine atoms in a trans disposition. Selected bond lengths $(\AA)$ and angles $\left(^{\circ}\right)$ are summarized in the caption of Fig. 1 .

We have found that the structure of compound $\mathbf{1}$ is one of the few examples found in the literature, in fact there is only one complex with a similar Pt-N distance in the literature, ${ }^{20}$ although in this case the geometry of the coordination environment may be influenced by the interaction of the $\mathrm{Pt}$ (II) with another nitrogen atom from the ligand. Pt-I distances,

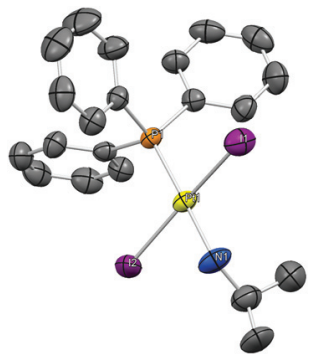

Fig. 1 Ellipsoid plot (50\% probability) of complex 1. Hydrogen atoms have been omitted for clarity. Selected bond lengths (A): Pt1-I1 = 2.6255(5), Pt1-12 = 2.5920(5), Pt1-N1 = 2.120(4), Pt1-P1 = 2.244(1); Selected bond angles $\left({ }^{\circ}\right)$ : $11-P t 1-12=172.33(2), \mid 1-P t 1-P 1=91.51(3)$, I1-Pt1-N1 = 87.8(2), I2-Pt1-P1 = 93.99(3), I2-Pt1-N1 = 86.5(2), N1$\mathrm{Pt1}-\mathrm{P} 1=177.4(1)$.

however, fall within the range of the reported values $(\mathrm{Pt}-\mathrm{I}=$ 2.567(1)-2.6763(6) А).

Compared to the recently reported $\mathrm{Pt}^{\mathrm{IV}}$ derivatives containing phosphines $\mathrm{PtCl}_{4}(\mathrm{ipa})\left(\mathrm{PPh}_{3}\right){ }^{21} \mathrm{Pt}-\mathrm{N}$ and $\mathrm{Pt}-\mathrm{P}$ distances found in compound $\mathbf{1}$ are very similar to the ones in the chlorido derivative ( $\mathrm{Pt}-\mathrm{N}=2.127(3) \AA$, and $\mathrm{Pt}-\mathrm{P}=2.2396(9) \AA$ ), and longer than the ones found in analogous $\mathrm{Pt}(\mathrm{II})$ complexes included in the CSD database, in which Pt-N distances range from 2.051(4) to 2.079(7) $\AA$, and Pt-P distances from 2.156(3) to $2.225(2) \AA .{ }^{17,22,23}$

\section{Cytotoxicity}

The $\mathrm{IC}_{50}$ values of the three trans-complexes were determined using a standard crystal violet staining assay (Table 1). Cisplatin was included as a positive control. The methylamine (3) and dimethylamine (2) complexes were determined to be universally inefficacious, with $\mathrm{IC}_{50}$ values beyond the range of concentrations applied. However, the isopropylamine (1) compound resulted in values in the same range as cisplatin for 3 of the cell lines, A375, HCT116-/- and SKOV3. The 10-fold lower cisplatin value for HCT116 wt reflects the known increased sensitivity of the cell line to cisplatin compared to the p53 null version of the cell line, HCT116(-/-). ${ }^{24}$ However the HCT116 wt cell line showed a similar sensitivity to the isopropylamine complex compared to cisplatin. Because the $\mathrm{IC}_{50}$ values for the trans complexes did not follow the same pattern in the HCT116 and HCT116(-/-) lines as cisplatin, it suggests that the $\mathrm{IC}_{50}$ value of $27 \mu \mathrm{M}$ for HCT116-/- occurred through a different mechanism of action and perhaps independent of p53 status. The result for complex 1 in the lines of HCT116 $(-/-)$, A375 and SKOV3 is lower than the value for cisplatin,

Table 1 Cytotoxic potency of Pt(II) complexes 1-3 on the different cell lines tested $\left(\mathrm{IC}_{50}, \mu \mathrm{M}\right)$

\begin{tabular}{lrrrrr}
\hline Complex & A375 & HCT116 & HCT116-l- & T47D & SKOV 3 \\
\hline $\mathbf{1}$ & 20 & $>100$ & 27 & $>100$ & 22 \\
2 & $>100$ & $>100$ & $>100$ & $>100$ & $>100$ \\
3 & $>100$ & $>100$ & $>100$ & $>100$ & $>100$ \\
CDDP & 51 & 5 & 47 & 60 & 73
\end{tabular}


suggesting a dissimilar mechanism that overcomes the known resistance of SKOV3 and HCT116(-/-) towards cisplatin. This is encouraging, as ERK1/2 phosphorylation occurs in A375 cells, offering protection from cisplatin-mediated apoptosis. ${ }^{11,25,26}$ In all cases it is worth pointing out that the complex with the most promise as an antitumor drug is the complex with the most bulky aliphatic amine ligand. In addition, the larger size of the $\mathrm{PPh}_{3}$ spectator ligand has been previously discussed to be responsible for increased DNA distortion, ${ }^{5}$ additionally the complex with the most promising $\mathrm{IC}_{50}$ value is the complex with the most bulky isopropylamine ligand (Table 1).

\section{Binding studies using DNA models: 9-EtG and pBR322}

We have studied the reactivity of the most active compound, $\mathbf{1}$ with 9-ethyl guanine (9-EtG) to model the reactions with DNA purine nucleobases. 9-EtG has been extensively used as a DNA model for metallodrugs studies, ${ }^{27,28}$ including iodido complexes bearing aliphatic amines, ${ }^{29}$ and has become a good model to allow for the comparison with these new phosphine diiodido derivatives. In our studies, the reaction of complex 1 with 9-EtG was monitored by ${ }^{1} \mathrm{H}$ NMR spectroscopy as described in the $\mathrm{ESI}^{\dagger}$ and recorded at different times over 24 hours incubation at $37{ }^{\circ} \mathrm{C}$ (Figure SM-B1).

The solubility of the new iodido complexes is higher than the chlorido derivatives, ${ }^{5}$ but in spite of this improved solubility, the problem of the concentration hasn't been fully overcome, as can be seen in the low resolution of the aromatic area of the spectra in Figure SM-B1. When following the changes in the $\mathrm{H} 8$ peak of 9-EtG, which is the most affected signal when the platination of the base takes place at N7, we can detected a broad signal which arises at ca. $8.00 \mathrm{ppm}$ corresponding to the $\mathrm{H} 8$ resonance of any possible new adduct. The spectra, as previously mentioned, showed low resolution probably caused by speciation. Another feature that supports speciation is the new signal at $6.4 \mathrm{ppm}$, which possibly belongs to the $\mathrm{H} 8$ of an additional species. The low concentration of the spectra does not allowed further experiments to be recorded, but it has been reported previously that H8 of 9-EtG can be extremely unshielded when is wedged between bulky groups. ${ }^{27}$

Most importantly, from the obtained spectra, we are sure that no isopropylamine free ligand is shown at $0.9 \mathrm{ppm}$ (methyl group from free ipa). So the new complexes react versus DNA in a classic manner, losing the iodido ligands. Moreover we can clearly see that the reactivity of this complex is much slower than the iodido reported previously, ${ }^{29,30}$ which after only 2 hours most of the 9EtG-free signal was already reacted. Complex 1, on the other hand, does show 9EtG-free (H8) signal as a major species, after 24 hours.

The DNA unwinding assay is a standard assay used to determine DNA interactions with platinum compounds. It is known that the binding of cisplatin introduces severe distortion in the DNA helix in the form of bending and unwinding of negative supercoils.

In this work, supercoiled pBR322 DNA was incubated with increasing amounts of complexes 1-3 and the amount of

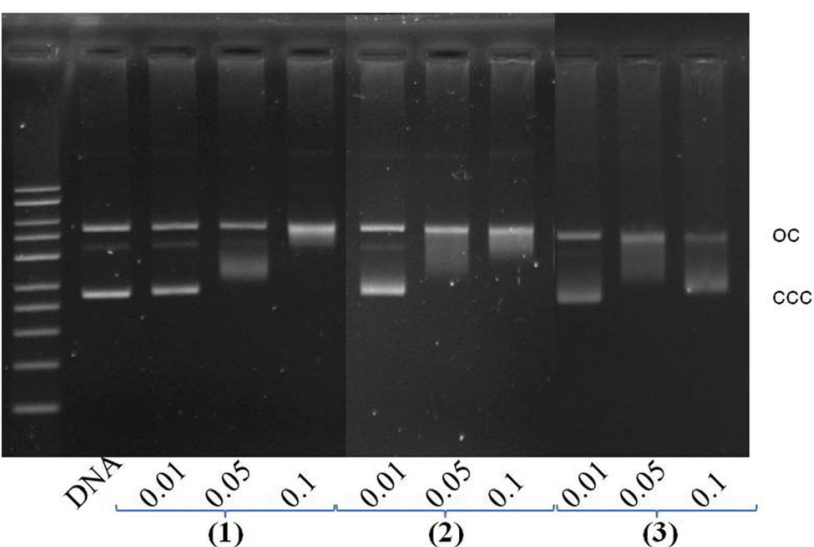

Fig. 2 Agarose gel electrophoresis of pBR322 plasmid treated with the trans Pt" complexes. Lane 1: Marker and lane 2: DNA of control plasmid. Plasmid DNA incubated at $r_{\mathrm{i}}=0.01,0.05$ and 0.1 with complexes 1 (lanes 3 to 5), complex 2 (lanes 6 to 8) and complex 3 (lanes 9 to 11). oc $=$ open circular DNA form; $c c c=$ covalently closed circular DNA.

unwinding at those complex : DNA ratios $\left(r_{\mathrm{i}}\right)$ was compared. All three complexes caused negatively supercoiled plasmid DNA to migrate more slowly on an agarose gel, confirming that negative supercoils are removed as the complexes bind. Complex 1 appears to completely relax the supercoils at an $r_{\mathrm{i}}$ of 0.1 , while the other complexes don't result in complete unwinding at these concentrations. This coincides with the toxicity data that follows showing the lack of efficaciousness of complexes 2 and 3 (Fig. 2).

However we must be careful making these kinds of comparisons because the active chloride parent complexes showed less distortion under the same conditions, yet demonstrated high cytotoxicity.

\section{Cell cycle studies}

Once the $\mathrm{IC}_{50}$ values were established for the various cell lines studied, a fixed concentration of complex was used to treat cultures in preparation for cell cycle analysis. They were treated exactly as cells used for $\mathrm{IC}_{50}$ establishment, but were fixed, PI (propidium iodide) stained and analysed for DNA/cell content. In the SKOV3 cell line, the cell cycle distribution was similar for all complexes tested and cisplatin (Fig. 3), while the trans complexes showed a lower overall G0/G1 accumulation. A similar result in SKOV3 was seen with other trans-dichloro Pt(II) complexes with phosphine ligands prepared by this group. ${ }^{5}$ The HCT116 wt cell line, showed a similar result. In comparison, however, the HCT116-/- cell line treated with cisplatin showed its typical G2/M accumulation, ${ }^{13,31}$ while none of the trans complexes showed comparable accumulation. Also notable is the increase in G0/G1 accumulation in A375 cells treated with trans complexes relative to cisplatin. Also interestingly, this was the only cell line with which a subG1 peak was noted with cisplatin treatment.

This presence of hypodiploid DNA in the histogram is suggestive of apoptosis, but should be interpreted with caution. ${ }^{32}$ This particular assay is incapable of definitively reporting apoptosis, however we can interpret the lack of a clear sub-G1 


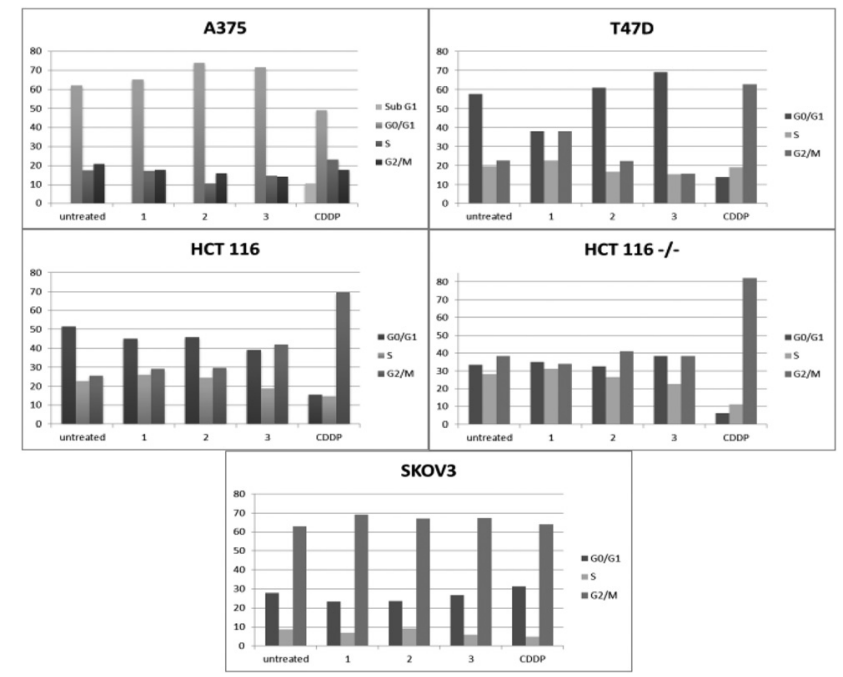

Fig. 3 Percent of cells at each cell cycle phase after treatment with trans-platinum (II) complexes 1-3 and cisplatin.

peak in the histogram of any of the trans-treated cells as indication of a clear difference in the mechanism of action from cisplatin in A375 melanoma cells.

It has been reported that longer treatment eventually results in cell cycle arrest as the cellular distribution profile changes over time, depending on repair deficiencies that may or may not exist in a particular cell line. ${ }^{31}$ However, in our previous experience, in we have seldom been able to find information or values that could help us to detect such differences with longer treatments. ${ }^{15}$ In this regard we are convinced that additional work can and should be done, and our plan is to use these compounds or some with similar and small structural variations to obtain more valuable information into possible differences in the mechanism of action of trans- $\mathrm{PPh}_{3}$ complexes.

\section{Conclusion}

Complexes with phosphine and aliphatic amines were synthesized and studied. The results showed similar cytotoxicity to cisplatin for complex $\mathbf{1}$, and such studies can be correlated to the unwinding pattern shown versus DNA. The structural studies of complex 1 represent a good candidate with which to evaluate the differences with similar complexes made previously. The biological studies indicates that complex 1 showed the most promising results versus cancer cell lines tested and it is the best candidate for further study into the biological action of these complexes.

\section{Experimental methods}

\section{Chemistry}

The starting material were prepared following a procedure previously described in our laboratory for cis- $\left[\mathrm{PtCl}_{2}\left(\mathrm{PPh}_{3}\right)_{2}\right]$ and trans-[ $\left[\mathrm{Pt}_{2} \mathrm{I}_{2}(\mu-\mathrm{I})_{2}\left(\mathrm{PPh}_{3}\right)_{2}\right]$ was synthesized as following:
A solution of $\mathrm{I}_{2}(208.1 \mathrm{mg}, 0.82 \mathrm{mmol})$ in $6 \mathrm{~mL}$ of $\mathrm{CH}_{2} \mathrm{Cl}_{2}$ was added in small portions $(1.5 \mathrm{~mL})$ to a solution of complex cis- $\left[\mathrm{PtCl}_{2}\left(\mathrm{PPh}_{3}\right)_{2}\right](500 \mathrm{mg}, 0.63 \mathrm{mmol})$ in $\mathrm{CH}_{2} \mathrm{Cl}_{2}$ and heated at $50{ }^{\circ} \mathrm{C}$. After 6 days, the reaction was cooled down at room temperature and the resulting red solid was filtrated, washed with cool $\mathrm{CH}_{2} \mathrm{Cl}_{2}$ and vacuum dried. Red Solid. Yield: $63 \%$ Elemental analysis: calculated $\mathrm{C}_{36} \mathrm{H}_{30} \mathrm{I}_{4} \mathrm{P}_{2} \mathrm{Pt}_{2} \cdot 0.7 \mathrm{CH}_{2} \mathrm{Cl}_{2}, \mathrm{C}$ : $29.75 \%$, H: $2.14 \%$; found: C: $29.61 \%, \mathrm{H}: 2.18 \% . \delta_{\mathrm{H}}(300 \mathrm{MHz}$; DMSO-d6) 7.67 (m, 6H, $\left.\mathrm{H}_{\text {ortho }}\right), 7.52$ (m, 9H, $\left.\mathrm{H}_{\text {meta-para }}\right)$. $\delta_{\mathrm{C}}\left(75.47 \mathrm{MHz} ;\right.$ DMSO-d6) $134.7\left(\mathrm{C}_{\text {ortho }}\right), 128.6\left(\mathrm{C}_{\text {meta }}\right), 131.6$ $\left(\mathrm{C}_{\text {para }}\right) . \delta_{\mathrm{P}}\left(300 \mathrm{MHz}\right.$; DMSO-d6) $18.14\left(J_{\mathrm{P}-\mathrm{Pt}}=3561.24 \mathrm{~Hz}\right)$. $\delta_{\mathrm{Pt}}\left(64.53 \mathrm{MHz} ; \quad \mathrm{DMSO}-\mathrm{d} 6 ; \mathrm{Na}_{2} \mathrm{PtCl}_{6}\right)$-4319.22. $\left(J_{\mathrm{Pt}-\mathrm{P}}=\right.$ $3805.18 \mathrm{~Hz})$. MS (ESI): $1444.72 \mathrm{amu}[\mathrm{M}+\mathrm{Na}]^{+}$.

\section{Method a: trans-[$\left[\operatorname{PtI}_{2}(\right.$ amine $\left.)\left(\mathbf{P P h}_{3}\right)\right]$ where amine:} methylamine and dimethylamine

A solution of 2 equivalents of $\mathrm{NaOH}$ in water was added to a mixture of trans-[ $\left[\mathrm{Pt}_{2} \mathrm{I}_{2}(\mu-\mathrm{I})_{2}\left(\mathrm{PPh}_{3}\right)_{2}\right](80 \mathrm{mg}, 0.056 \mathrm{mmol})$ and the desired amine: methylamine hydrochloride $(7.5 \mathrm{mg}$, $112 \mathrm{mmol})$, dimethylamine hydrochloride $(9.12 \mathrm{mg}$, $0.112 \mathrm{mmol}$ ) in chloroform and stirred in darkness at room temperature for 2 days. The resulting orange solution was dried to a crude solid which was purified by redissolving in diethyl ether. The final solution was left at room temperature to slowly evaporate and the final product was isolated as an orange solid.

trans-[PtI $\left.{ }_{2}(\mathbf{d m a})\left(\mathbf{P P h}_{3}\right)\right]$. Orange solid. Yield: $71 \%$. Elemental analysis: calculated $\mathrm{C}_{20} \mathrm{H}_{22} \mathrm{NI}_{2} \mathrm{PPt} \cdot\left(\mathrm{CH}_{3}\right)_{2} \mathrm{CO}: \mathrm{C}: 33.92 \%, \mathrm{H}$ : $3.47 \%$, N: $1.72 \%$. CHN; found: C: $34.53 \%$, H: $3.34 \%$, N: $1.63 \%$. $\delta_{\mathrm{H}}\left(300 \mathrm{MHz}\right.$; acetone-d6) $7.72\left(\mathrm{~m}, 6 \mathrm{H}, \mathrm{H}_{\text {ortho }}\right), 7.42(\mathrm{~m}, 9 \mathrm{H}$, $\mathrm{H}_{\text {meta-para }}$ ), 4.68 (bs, $\left.1 \mathrm{H}, \mathrm{NH}\right), 2.80$ (d, 6H, $\mathrm{CH}_{3}$-dma). $\delta_{\mathrm{C}}\left(75.47 \mathrm{MHz}\right.$; acetone-d6) $135.1\left(\mathrm{C}_{\text {ortho }}\right), 127.5\left(\mathrm{C}_{\text {meta }}\right), 130.5$ $\left(\mathrm{C}_{\text {para }}\right), 42.2\left(\mathrm{CH}_{3}-\mathrm{ma}\right) . \delta_{\mathrm{P}}(300 \mathrm{MHz}$; acetone-d6 $)-1.2\left(J_{\mathrm{P}-\mathrm{Pt}}=\right.$ $3262.22 \mathrm{~Hz}) . \delta_{\mathrm{Pt}}\left(64.53 \mathrm{MHz}\right.$; acetone-d6; $\left.\mathrm{Na}_{2} \mathrm{PtCl}_{6}\right)-4933.6$ $\left(J_{\mathrm{Pt}-\mathrm{P}}=3262.37 \mathrm{~Hz}\right)$. MS (ESI): $755.9 \mathrm{amu}[\mathrm{M}]^{+}$.

trans-[$\left[\mathbf{P t I}_{2}(\mathbf{m a})\left(\mathbf{P P h}_{3}\right)\right]$. Orange solid. Yield: $60 \%$. Elemental analysis: calculated $\mathrm{C}_{19} \mathrm{H}_{20} \mathrm{NI}_{2} \mathrm{PPt} \cdot 0.6 \mathrm{CHCl}_{3} \cdot 0.6 \mathrm{C}_{4} \mathrm{H}_{10} \mathrm{O}: \quad \mathrm{C}$ : $30.64 \%, \mathrm{H}: 3.11 \%, \mathrm{~N}: 1.62 \%$. CHN; found: C: $30.97 \%, \mathrm{H}:$ $2.72 \%, \mathrm{~N}: 1.62 \% . \delta_{\mathrm{H}}\left(300 \mathrm{MHz} ; \mathrm{CDCl}_{3}\right) 7.71\left(\mathrm{~m}, 6 \mathrm{H}, \mathrm{H}_{\text {ortho }}\right)$, $7.40\left(\mathrm{~m}, 9 \mathrm{H}, \mathrm{H}_{\text {meta-para }}\right), 2.72\left(\mathrm{~d}, 3 \mathrm{H}, \mathrm{CH}_{3}-\mathrm{ma}, J_{\mathrm{H}-\mathrm{H}}=7 \mathrm{~Hz}\right)$. $\delta_{\mathrm{C}}\left(75.47 \mathrm{MHz} ; \mathrm{CDCl}_{3}\right) 135.5\left(\mathrm{C}_{\text {ortho }}\right), 128.6\left(\mathrm{C}_{\text {meta }}\right), 131.4\left(\mathrm{C}_{\text {para }}\right)$, 24.5 $\left(\mathrm{CH}_{3}-\mathrm{ma}\right) . \delta_{\mathrm{P}}\left(300 \mathrm{MHz} ; \mathrm{CDCl}_{3}\right) 0.9\left(J_{\mathrm{P}-\mathrm{Pt}}=3412.32 \mathrm{~Hz}\right)$. $\delta_{\mathrm{Pt}}\left(64.53 \mathrm{MHz} ; \mathrm{CDCl}_{3} ; \mathrm{Na}_{2} \mathrm{PtCl}_{6}\right)-5045.5\left(J_{\mathrm{Pt}-\mathrm{P}}=3411.31 \mathrm{~Hz}\right)$.

\section{Method b: trans-[ $\operatorname{PtI}_{2}($ amine $\left.)\left(\mathbf{P P h}_{3}\right)\right]$ where amine: isopropylamine}

A mixture of trans-[ $\left[\mathrm{Pt}_{2} \mathrm{I}_{2}(\mu-\mathrm{I})_{2}\left(\mathrm{PPh}_{3}\right)_{2}\right](80 \mathrm{mg}, 0.056 \mathrm{mmol})$ and isopropylamine $(130 \mu \mathrm{l}, 1.5 \mathrm{mmol})$ in chloroform was stirred in darkness at room temperature for 2 days. The resulting orange solution was dried to a crude solid which was purified by redissolving in diethyl ether. The final solution was left at room temperature to slow evaporation to isolate the final product as an orange solid.

trans-[PtI $\left.(\mathbf{i p a})\left(\mathbf{P P h}_{3}\right)\right]$. Orange solid. Yield: $71 \%$. Elemental analysis calculated for $\mathrm{C}_{21} \mathrm{H}_{24} \mathrm{I}_{2} \mathrm{NPPt} \cdot 1.3 \mathrm{C}_{4} \mathrm{H}_{10} \mathrm{O}: \mathrm{C}: 36.31 \%, \mathrm{H}$ : $4.03 \%, \mathrm{~N}: 1.62 \%$ CHN found: C: $36.99 \%, \mathrm{H}: 3.52 \%$, N: $1.85 \%$. 
$\delta_{\mathrm{H}}\left(300 \mathrm{MHz} ; \mathrm{CDCl}_{3}\right) 7.73\left(\mathrm{~m}, 6 \mathrm{H}, \mathrm{H}_{\text {ortho }}\right), 7.71(\mathrm{~m}, 9 \mathrm{H}$, $\mathrm{H}_{\text {meta-para }}$ ), 3.84 (sp, 1H, CH-ipa), 3.51 (bs, 2H, $\mathrm{NH}_{2}$ ), 1.38 (d, $6 \mathrm{H}, \mathrm{CH}_{3}$-ipa). $\delta_{\mathrm{C}}\left(75.47 \mathrm{MHz} ; \mathrm{CDCl}_{3}\right) 135.1\left(\mathrm{C}_{\text {ortho }}\right), 132.8\left(\mathrm{C}_{\text {ipso }}\right)$ 130.6( $\left.\mathrm{C}_{\text {para }}\right), \quad 127.5\left(\mathrm{C}_{\text {meta }}\right), \quad 40.0$ ( $\mathrm{CH}$-ipa $), \quad 25.4\left(\mathrm{CH}_{3}\right.$-ipa $)$. $\delta_{\mathrm{P}}\left(300 \mathrm{MHz} ; \mathrm{CDCl}_{3}\right) 0.9\left(J_{\mathrm{P}-\mathrm{Pt}}=3407.28 \mathrm{~Hz}\right) . \delta_{\mathrm{Pt}}(64.53 \mathrm{MHz}$; $\left.\mathrm{CDCl}_{3} ; \mathrm{Na}_{2} \mathrm{PtCl}_{6}\right)-5004.9\left(J_{\mathrm{Pt}-\mathrm{P}}=3407.28 \mathrm{~Hz}\right)$. MS (MALDITOF): 771 amu $[\mathrm{M}-\mathrm{H}]^{+}$.

\section{Biology}

pBR322 binding studies and conditions. The DNA binding studies were performed in a total volume of $20 \mu \mathrm{l}$. The DNA aliquots containing $8 \mu \mathrm{L}$ of DNA-pBR322 (10 $\mathrm{ng} \mathrm{mL}^{-1}$ stock) in $10 \mathrm{mM}$ Tris-HCl ( $\mathrm{pH}$ 7.6) and $1 \mathrm{mM}$ EDTA were incubated with the platinum compounds at several $r_{i}$ values (0.001 to 0.1) using the corresponding amount of platinum from either a $5 \mu \mathrm{M}$ or $50 \mu \mathrm{M}$ stock solution. The samples were incubated at $37^{\circ} \mathrm{C}$ for $24 \mathrm{~h}$, after which time $2 \mu \mathrm{L}$ of a loading dye containing $50 \%$ glycerol, $0.25 \%$ bromophenol blue and $0.25 \%$ xylene cyanol was added. The entire sample $(20 \mu \mathrm{L})$ was loaded in the wells of a $0.8 \%$ agarose gel. Electrophoresis was carried out for a period of $2.5 \mathrm{~h}$ at approximately $50 \mathrm{~V}$. After electrophoresis, the gel was immersed in $800 \mathrm{~mL}$ of Millipore water containing $64 \mu \mathrm{L}$ of a $10 \mathrm{mg} \mathrm{mL}^{-1}$ stock solution of ethidium bromide for 30 minutes to stain the DNA.

Cytotoxicity. The following cell lines were used in this work: A375, human malignant melanoma and SKOV3 human ovarian adenocarcinoma (both from ATCC, Manassas, VA); T47D, breast duct epithelial carcinoma, HCT116, human colorectal carcinoma (both a gift from Paul Miller, Johns Hopkins University); and HCT116(-/-), (a gift from Margaret Wear, Uniformed Services University of the Health Sciences, Bethesda, MD) All cell lines were maintained in monolayers in humidified air with $5 \% \mathrm{CO}_{2}$ at $37{ }^{\circ} \mathrm{C}$ in Dulbecco's Modified Eagle Media- $\alpha$ (DMEM- $\alpha$ ) with the exception of HCT116(-/-) and T47D, which were maintained in RPMI media. All media contained $10 \%$ fetal bovine serum, and $1 \times$ streptomycin/ampicillin. To determine cytotoxicity, cells were seeded at a density of 4000 cells per well in a 96-well plate. The cells were allowed to attach and recover for 48 hours and then were treated in triplicate with $0.2 \mathrm{~mL}$ of increasing concentrations of drug diluted in media. Compounds 1-3 were diluted from a $10 \mathrm{mM}$ stock of compound freshly dissolved in DMSO; while cisplatin stock was prepared to $5 \mathrm{mM}$ in PBS (phosphate buffered saline). The compound remained on the cells for 2 hours, after which the media containing drug was aspirated and replaced with fresh media. After another 24 hours, the cells were washed twice with PBS, then fixed in 10\% glutaraldehyde for 15 minutes. The cells were again washed twice with PBS, then stained with $0.25 \%$ crystal violet at $37{ }^{\circ} \mathrm{C}$ for 15 minutes. They were then extensively washed with PBS and the remaining dye

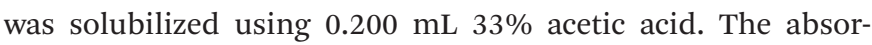
bance of purple color was quantified at $595 \mathrm{~nm}$ using a Tecan Sunrise Absorbance plate reader.

Cell cycle analysis. To conduct cell cycle analysis, all cell lines were seeded at a density of 75000 cells per well in a 12-well plate. The cells were allowed to attach and recover for
24 hours and then were treated with $1.0 \mathrm{~mL}$ of 50 or $10 \mu \mathrm{M}$ drug diluted in media. Compounds 1-3 were diluted from $100 \mathrm{mM}$ stock of compound freshly dissolved in DMSO; while cisplatin was administered at $50 \mu \mathrm{M}$ concentration and was diluted from a stock that was prepared to $5 \mathrm{mM}$ in PBS. The compound remained on the cells for 48 hours, after which the media containing drug was aspirated and replaced with fresh media. After treatment, the cells were washed and trypsinized to detach them from the plate. The cells were suspended in $1 \mathrm{~mL}$ fresh media and transferred to a polystyrene culture tube. The cells were pelleted at $450 g$ for 5 minutes in a swing bucket centrifuge and washed twice with $1 \mathrm{~mL}$ of PBS. After pelleting, the washed cells they were resuspended in $0.25 \mathrm{~mL}$ PBS to which $2.25 \mathrm{~mL}$ ice cold $70 \%$ ethanol was added slowly with vortexing. This suspension remained at $-20{ }^{\circ} \mathrm{C}$ until cell sorting. Just prior to cell cycle analysis, the cells were pelleted at $450 \mathrm{~g}$ for 5 minutes, washed with $1 \mathrm{~mL}$ PBS and pelleted again. To the cell pellet, $0.2 \mathrm{~mL}$ of Guava Cell Cycle Reagent (Millipore) was added, and the cells were allowed to incubate at room temperature for 30 minutes in the dark. The samples were analysed for cell cycle distribution using a Guava Easy Cyte Flow Cytometer and Guava CytoSoft Analysis software.

\section{Acknowledgements}

The Spanish Ministerio de Economia y Competitividad has supported this work with the grant: SAF2012-34424. This work was also supported by a School of the Sciences, Stevenson University Seed Grant. We would like to thank Prof. Carmen Navarro-Ranninger for her support along our scientific career and projects.

\section{Notes and references}

1 N. J. Wheate, S. Walker, G. E. Craig and R. Oun, Dalton Trans., 2010, 39, 8113-8127.

2 A. M. Sheena and N. P. Farrell, Eur. J. Inorg. Chem., 2009, 1293-1302.

3 A. G. Quiroga, J. Inorg. Biochem., 2012, 114, 106-112.

4 U. Kalinowska-Lis, J. Ochocki and K. Matlawska-Wasowska, Coord. Chem. Rev., 2008, 252, 1328-1345.

5 F. J. Ramos-Lima, A. G. Quiroga, B. Garcia-Serrelde, F. Blanco, A. Carnero and C. Navarro-Ranninger, J. Med. Chem., 2007, 50, 2194-2199.

6 F. J. Ramos-Lima, A. G. Quiroga, J. M. Perez, M. FontBardia, X. Solans and C. Navarro-Ranninger, Eur. J. Inorg. Chem., 2003, 1591-1598.

7 L. Cubo, A. G. Quiroga, J. Zhang, D. S. Thomas, A. Carnero, C. Navarro-Ranninger and S. J. Berners-Price, Dalton Trans., 2009, 3457-3466.

8 L. Messori, L. Cubo, C. Gabbiani, A. Alvarez-Valdes, E. Michelucci, G. Pieraccini, C. Rios-Luci, L. G. Leon, J. M. Padron, C. Navarro-Ranninger, A. Casini and A. G. Quiroga, Inorg. Chem., 2012, 51, 1717-1726. 
9 A. Carnero, Br. J. Cancer, 2002, 87, 129-133.

10 M. Malumbres and M. Barbacid, Nat. Rev. Cancer, 2009, 9, 153-166.

11 Z. H. Siddik, Oncogene, 2003, 22, 7265-7279.

12 C. M. Sorenson, M. A. Barry and A. Eastman, J. Natl. Cancer Inst., 1990, 82, 749-755.

13 A. Boccarelli, D. Giordano, G. Natile and M. Coluccia, Biochem. Pharmacol., 2006, 72, 280-292.

14 T. Servidei, C. Ferlini, A. Riccardi, D. Meco, G. Scambia, G. Segni, C. Manzotti and R. Riccardi, Eur. J. Cancer, 2001, 37, 930-938.

15 F. J. Ramos-Lima, V. Moneo, A. G. Quiroga, A. Carnero and C. Navarro-Ranninger, Eur. J. Med. Chem., 2010, 45, 134-141.

16 A. N. Biswas, V. Bagchi, P. Das and P. Bandyopadhyay, Acta Crystallogr., Sect. E: Struct. Rep. Online, 2007, 63, M2836U1913.

17 E. S. Tabei, H. Samouei and M. Rashidi, Dalton Trans., 2011, 40, 11385-11388.

18 W. Henderson and S. R. Alley, Inorg. Chim. Acta, 2001, 322, 106-112.

19 G. Guerrero, P. H. Mutin, F. Dahan and A. Vioux, J. Organomet. Chem., 2002, 649, 113-120.

20 F. P. Fanizzi, L. Maresca, G. Natile, M. Lanfranchi, A. Tiripicchio and G. Pacchioni, J. Chem. Soc., Chem. Commun., 1992, 333-335.

21 M. A. Medrano, A. Alvarez-Valdes, J. Perles, J. Lloret-Fillol, S. Munoz-Galvan, A. Carnero, C. Navarro-Ranninger and A. G. Quiroga, Chem. Commun., 2013, 49, 4806-4808.
22 M. H. Thibault, B. E. G. Lucier, R. W. Schurko and F. G. Fontaine, Dalton Trans., 2009, 7701-7716.

23 H. A. Ankersmit, B. H. Loken, H. Kooijman, A. L. Spek, K. Vrieze and G. vanKoten, Inorg. Chim. Acta, 1996, 252, 141-155.

24 S. Y. Sharp, C. F. O’Neill, P. Rogers, F. E. Boxall and L. R. Kelland, Eur. J. Cancer, 2002, 38, 2309-2315.

25 A. Mirmohammadsadegh, R. Mota, A. Gustrau, M. Hassan, S. Nambiar, A. Marini, H. Bojar, A. Tannapfel and U. R. Hengge, J. Invest. Dermatol., 2007, 127, 2207-2215.

26 D. Wang and S. J. Lippard, Nat. Rev. Drug Discovery, 2005, 4, 307-320.

27 A. C. G. Hotze, E. P. L. van der Geer, S. E. Caspers, H. Kooijman, A. L. Spek, J. G. Haasnoot and J. Reedijk, Inorg. Chem., 2004, 43, 4935-4943.

28 A. H. Velders, A. G. Quiroga, J. G. Haasnoot and J. Reedijk, Eur. J. Inorg. Chem., 2003, 2003, 713-719.

29 L. Messori, L. Cubo, C. Gabbiani, A. Alvarez-Valdes, E. Michelucci, G. Pieraccini, C. Ríos-Luci, L. G. León, J. M. Padrón, C. Navarro-Ranninger, A. Casini and A. G. Quiroga, Inorg. Chem., 2012, 51, 1717-1726.

30 T. Parro, M. A. Medrano, L. Cubo, S. Muñoz-Galván, A. Carnero, C. Navarro-Ranninger and A. G. Quiroga, J. Inorg. Biochem., 2013, 127, 182-187.

31 V. Beljanski, L. G. Marzilli and P. W. Doetsch, Mol. Pharmacol., 2004, 65, 1496-1506.

32 M. G. Ormengod, Leukemia, 1998, 12, 1013-1025. 